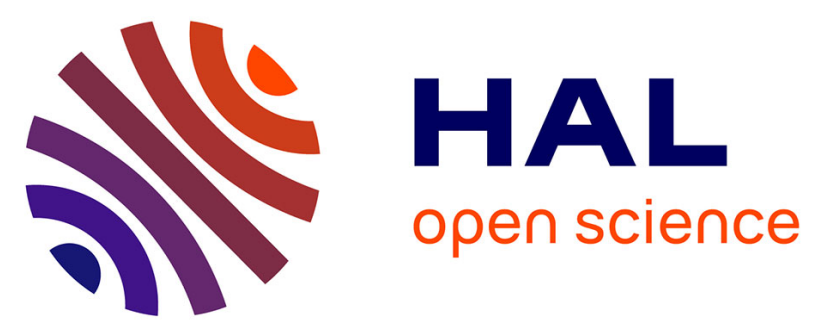

\title{
Mobilising common biocultural heritage for the socioeconomic inclusion of small farmers: panarchy of two case studies on quinoa in Chile and Bolivia
}

Thierry Winkel, Lizbeth Núñez-Carrasco, Pablo José Cruz, Nancy Egan, Luís Sáez-Tonacca, Priscilla Cubillos-Celis, Camila Poblete-Olivera, Natalia Zavalla-Nanco, Bárbara Miño-Baes, Maria-Paz Viedma-Araya

\section{To cite this version:}

Thierry Winkel, Lizbeth Núñez-Carrasco, Pablo José Cruz, Nancy Egan, Luís Sáez-Tonacca, et al.. Mobilising common biocultural heritage for the socioeconomic inclusion of small farmers: panarchy of two case studies on quinoa in Chile and Bolivia. Agriculture and Human Values, 2020, 37, pp.433-447. 10.1007/s10460-019-09996-1 . ird-02381132

HAL Id: ird-02381132

https://hal.ird.fr/ird-02381132

Submitted on 13 Oct 2021

HAL is a multi-disciplinary open access archive for the deposit and dissemination of scientific research documents, whether they are published or not. The documents may come from teaching and research institutions in France or abroad, or from public or private research centers.
L'archive ouverte pluridisciplinaire HAL, est destinée au dépôt et à la diffusion de documents scientifiques de niveau recherche, publiés ou non, émanant des établissements d'enseignement et de recherche français ou étrangers, des laboratoires publics ou privés. 
WINKEL Thierry, NÚÑEZ-CARRASCO Lizbeth, CRUZ Pablo José, EGAN Nancy, SÁEZ-TONACCA Luís, CUBILlOS-CELIS Priscilla E, POBLETE-OLIVERA Camila J, ZAVALLA-NANCO Natalia O, MIÑO-BAES Bárbara, VIEDMA-ARAYA Maria-Paz. 2020. Mobilising common biocultural heritage for the socioeconomic inclusion of small farmers: panarchy of two case studies on quinoa in Chile and Bolivia. Agriculture and Human Values 37: 433-447. URL: https://doi.org/10.1007/s10460-019-09996-1.

\section{Abstract}

Valorising the biocultural heritage of common goods could enable peasant farmers to achieve socially and economically inclusive sustainability. Increasingly appreciated by consumers, peasant heritage products offer small farmers promising opportunities for economic, social and territorial development. Identifying the obstacles and levers of this complex, multi-scale and multi-stakeholder objective requires an integrative framework. We applied the panarchy conceptual framework to two cases of participatory research with small quinoa producers: a local fair in Chile and quinoa export production in Bolivia. In both cases, the "commoning" process was crucial both to bring stakeholders together inside their communities and to gain outside recognition for their production and thus achieve social and economic inclusion. Despite the differences in scale, the local fair and the export market shared a similar marketing strategy based on short value chains promoting quality products with high identity value. In these dynamics of biocultural heritage valorisation, the panarchical approach revealed the central place as well as the vulnerability of the community territory. As a place of both

22 anchoring and opening, the community territory is the privileged space where autonomous and consensual control over the governance of common biocultural resources can be exercised.

\section{$24 \quad$ Keywords}

adaptive cycle; inclusive agriculture; participatory action research; short value chain; territorial 


\section{Contact information}

T. Winkel (corresponding author): thierry.winkel@ird.fr ; Centre d'Écologie Fonctionnelle et Évolutive (CEFE), Institut de Recherche pour le Développement (IRD), CNRS, Université de Montpellier, UPVM3, EPHE, Montpellier, France

32 L. Núñez-Carrasco (corresponding author): Inunez@ucm.cl ; Facultad de Ciencias Sociales, Universidad Católica del Maule (UCM), Curicó, Chile

\section{P. J. Cruz: pablocruz@conicet.gov.ar ; Unidad Ejecutora en Ciencias Sociales Regionales y} Humanidades (UE CISOR), Consejo Nacional de Investigaciones Científicas y Técnicas (CONICET), Universidad Nacional de Jujuy (UNJU), San Salvador de Jujuy, Argentina

N. Egan: nancyegan1@gmail.com ; Instituto de Investigaciones en Ciencias Sociales y Humanas, Universidad Nacional de Jujuy (UNJU), San Salvador de Jujuy, Argentina

L Sáez-Tonacca: luis.saez@usach.cl ; Departamento de Gestión Agraria, Universidad de Santiago de Chile (USACH), Santiago, Chile

P. Cubillos-Celis: priscilla.cubillos@gmail.com ; Facultad de Ciencias Sociales, Universidad

42 Católica del Maule (UCM), Curicó, Chile

C. Poblete-Olivera : camilapobleteolivera@hotmail.com ; Facultad de Ciencias Sociales,

44 Universidad Católica del Maule (UCM), Curicó, Chile

N. Zavalla-Nanco: nataliazavalla@hotmail.com ; Facultad de Ciencias Sociales, Universidad 46 Católica del Maule (UCM), Curicó, Chile

B. Miño-Baes: barbarambaes@hotmail.com ; Facultad de Ciencias Sociales, Universidad Católica del Maule (UCM), Curicó, Chile

M. P. Viedma-Araya: mariapazviedma@gmail.com ; Facultad de Ciencias Sociales, Universidad 50 Católica del Maule (UCM), Curicó, Chile 
Thierry Winkel is a research agroecologist in the Centre of Functional and Evolutionary Ecology at the Institute of Research for Development, France. His research expertise includes sustainability in low-input agrosystems in the arid areas, with an emphasis on integrating social and ecological responses to global change in the long term.

Lizbeth Núñez-Carrasco is a Professor-Researcher in the School of Social Work at Maule's

58 Catholic University, Chile. Her research focuses on the social dimensions of territorial management in rural areas and involves participative research with farmers, civil society organizations, and local authorities.

Pablo Cruz is a Senior Researcher in the Centre of Social Regional Sciences and Humanities at CONICET, and Professor in social sciences at Jujuy's National University, Argentina. His research interests relate to cultural anthropology, social change and archaeology in Andean societies.

64 Nancy Egan is a Professor-Researcher at Jujuy's National University and also affiliated with the Centre of Social Regional Sciences and Humanities, Argentina. Her research interests relate to cultural anthropology and history in Andean societies.

Luís Sáez-Tonacca is a Professor-Researcher in the Department of Rural Management at the

68 University of Santiago, Chile. With an expertise in agricultural economics, sustainable rural development and short value chains, he develops participative research in smallholder agriculture.

Priscilla Cubillos, Camila Poblete, Natalia Zavalla, Bárbara Miño and Maria-Paz Viedma were

72 students in Social Work at Maule's Catholic University, Chile. All five of them were interested in participative research and action with local stakeholders in the rural sector.

\section{Acknowledgements}

This work received financial support from CONICYT (National Council for Scientific and 76 Technological Research, Chile: Project PAI-80160043 BAQUIANA, UCM/IRD), MSH (Maison des Sciences de I'Homme SUD, France: Project PANARCHI 2017-2018, IRD/CNRS/UCM/UNJU) and 
78 ANR (The French National Research Agency, France: Project ANR-06-PADD-011-EQUECO). We thank Pablo Jara-Valdivia and Marcela Calquín for their contributions to the participatory

80 process with the Lipimávida community, and Mathieu Dionnet, co-organiser of the workshop "Common goods and participatory methods" (MSH-SUD, 16-18/05/2018, Montpellier, France).

82 We are all indebted to the producers, development agents and local authorities involved with us in these projects. Thanks are also due to the reviewers whose comments greatly improved 84 the paper. 
Activating the biocultural heritage of peasant ${ }^{1}$ agriculture has been proposed to promote the social and economic inclusion of the peasant sector in a perspective of sustainable and inclusive agriculture (Walshe and Argumedo 2016; Swiderska et al. 2018). For millennia, peasant agriculture has satisfied the food needs of most of humanity, modelled rural landscapes and maintained agrobiodiversity. It thus represents a form of biocultural heritage that encompasses a range of natural and cultural objects-from genes to landscapes, from knowledges to practices-all rooted in the history and ecology of local societies (Gavin et al. 2015).

Yet, despite its recent recognition by international organisations-FAO declared 2014 "International Year of Family Farming" - and by consumers who express a growing demand for quality products with a local identity, peasant agriculture remains marginal in public policies. In a majority of countries, these policies continue to promote the fragmentation of family farms in favour of the agro-industrial sector, whose environmental, social, ethical and aesthetic costs are however increasingly criticised as they become more widespread (e.g. epizootic outbreaks, soil degradation, biodiversity loss, farmers' indebtedness, livestock cruelty, destruction of amenities) (loris 2016).

In response, a number of alternatives seek to promote the specificities of peasant agriculture around the values of territorial identity and biocultural heritage. Because of their socio-cultural and local roots, the objects of the peasant heritage (e.g. landraces, vernacular architecture or gastronomy) are distinctive of the territory. As such, they become vectors of social and territorial identity for those who produce them and, being increasingly valued by consumers, they also become opportunities for the economic inclusion of peasant farmers, for example in 108 fair-trade or short supply chains.

\footnotetext{
${ }^{1}$ We define peasants as agricultural producers bound to their land, customs and culture, combining autonomy with community-oriented decisions (Van der Ploeg 2018). Peasants are not limited to premodern subsistence agriculture, and many of them are long-standing actors of the economic market (Soper 2016; Van der Ploeg 2018). We use the term "peasant agriculture" instead of the commonly used term "family agriculture" to focus on the farming model (peasant farming vs. entrepreneurial farming) implemented by these producers rather than on their social status as family units.
} 
Territorial identity, as a form of collective symbolic capital, may be activated through distinguishing signs linked to a place, know-how, or product, which reinforce social identity and inclusion and also contribute to the protection of common natural resources (Macías Vázquez and Alonso González 2015; Colloredo-Mansfeld 2011). The promotion of symbolic capital can therefore increase the economic value of material productions from agriculture, food

114 processing or handicrafts. But this process of creation/accumulation of symbolic capital runs the risk of being appropriated by exogenous actors mandated by private interests to capture the value generated by local communities (Macías Vázquez and Alonso González 2015). When they are emblematic of a territory, biocultural heritage objects have an obvious dimension of common goods, even in the case of private properties like buildings (e.g. Andalusians windmills, Gascony dovecotes...) or privately-owned animals of local breeds (e.g. Scottish Highland cattle, Chilean Araucana chickens...). The conception of biocultural objects as-at least partiallycommon goods is also supported by their transgenerational value as they are both an

122 inheritance from the past (even recent) and a legacy for the future, and not only the property of their current owners.

124 Another way to value peasant biocultural heritage is through fair-trade and short value chains, directly connecting producers and consumers (Contreras et al. 2014). Short value chains are not necessarily local: they may be short because of the small number of intermediaries, not because of geographical distance. In fact, in several cases, peasant producers see the export market as more stable and fair than the domestic market (Soper 2016). The concept of nested markets describes arrangements that allow small local producers to access increasingly

130 globalised markets without losing control over the production process and local/global connections (Grivins and Tisenkopfs 2018). Consumer awareness of these local/global connections and their solidarity with producers are key factors for the socio-economic inclusion of small farmers (Castaldo et al. 2009). Successful initiatives of community-supported 134 agriculture around the world show that this alternative model is also economically viable (BlayPalmer et al. 2016). 
136 The announced benefits of inclusive development point to greater prosperity and economic equity for more people and territories (Chakrabarti 2014). But inclusion requires not only

138 attention to the excluded: it also needs an explicit transformational strategy to align current economic and political trajectories with long-term ecological and social realities (Beling et al.

140 2018, De Schutter 2011). Two major obstacles arise there: the dominant discourse on the virtues of globalised commercialisation and the apolitical tradition of many social organisations

142 (Isgren and Ness 2017). To overcome them, some suggest replacing the narrow concepts of development and growth with those of inclusive sustainability (Essex and Read 2016) and good

144 living (Beling et al. 2018), which prioritise economic localisation and cooperation among social actors in an integrating and ethical vision of their ecological and social responsibilities. Beyond

146 economic growth, peer cooperation creates a protective space to jointly tackle socio-economic and environmental uncertainties. Cooperation generates common knowledge through shared

148 learning of practical skills in management, marketing or communication and, at the same time, strengthens the autonomy of local actors vis-à-vis uncontrolled outsiders (Lucas et al. 2016).

150 In practice, the participatory valorisation of a biocultural heritage includes: context analysis, rescue of the heritage object to be promoted, and shared design, all of which are interrelated.

152 In shared design, the promoters of the initiative-often technical institutions, NGOs or universities - can suggest objectives and methods that local actors reinterpret and appropriate

154 in the participatory processes. To access the market, some consider it necessary to improve the quantity and quality of the product in order to achieve a high and homogeneous standard, a

156 process that would imperatively require the support of technological institutions (FIA 2015). However, support institutions must guard against the temptation of "command-and-control"

158 that can undermine the empowerment of local actors (Cox 2016).

Quinoa provides exemplary cases that facilitate a more complete analysis of the question of 160 peasant inclusion through the valorisation of biocultural heritage. This ancestral grain from the Andean highlands and the Chilean coast is emblematic of the rescue and valorisation of the 162 agricultural heritage in Bolivia since the 1970s (Barrientos et al. 2017; Winkel et al. 2014, 2015) and more recently in Chile and Peru (Bedoya-Perales et al. 2018; Delatorre-Herrera et al. 2013; 
164 Lacoste et al. 2017; Núñez and Bazile 2009, 2010). Quinoa is promoted in the media as a superfood, both healthy (high in protein, gluten-free) and authentic (under the questionable

166 slogan of "rice of the Incas"). Its production by small, largely organic farmers, has further enhanced quinoa's popularity. While the rise of quinoa has allowed many peasant producers access to the global market and to thus achieve socioeconomic inclusion, it also poses real or potential environmental, social, and economic risks, which could lead to the exclusion of small producers and benefit economic agents better prepared to face these risks. Multiple actors with different motivations and priorities (governments, networks and transnational

172 corporations, etc.) question the relative control of quinoa production and commercialisation by small producers and their organisations (Zandstra 2015).

174 The growing complexity of quinoa's value chain has led to reflections on inclusive models for peasant producers that can generate social, environmental, and economic benefits for all in the

176 value chain. Recent studies focusing on Bolivia and Peru-the world's leading exporters of quinoa-point to the association of producers and collaborations between producers, processors, traders, and consumers as levers in an inclusive model (Ofstehage 2011,2012; Böhm 2016; Zandstra 2015).

180 Unlike highland Andean countries like Bolivia, whose production has dominated the world market for decades and remained in the hands of small farmers' organisations with only late 182 governmental support (Laguna 2011; Zandstra 2015), in Chile the recent expansion of quinoa has been driven by state institutions for technical assistance, training, and credit, involving both

184 small producers and a dynamic agribusiness sector (PUC 2017). Despite their socioeconomic specificities, in both countries the structure of the economy is based on the exploitation of natural resources for export, and peasant family agriculture remains marginal in terms of GDP, marked by structural poverty and social exclusion (Salcedo and Guzmán 2014).

188 Theoretical and methodological framework

This study on biocultural heritage, commons, and inclusive economy uses a methodology of participatory action research in the field and a panarchy conceptual framework for the integrative analysis of complex socio-ecological transformations. We consider complexity 
192 intrinsic to any socio-ecological interplay that includes a multiplicity of scales (space, time), domains (social, environmental, economic, cultural) and objectives (stability, growth or 194 reduction) (Kajikawa 2008).

Biocultural heritage, commons and inclusive economy

196 By definition, biocultural heritage is both a vector of identity - a heritage of a common local past-and of sustainability, considered of sufficient socio-economic, cultural, or environmental 198 importance to be transmitted to future generations. Our working hypothesis is that the activation of complex socio-environmental dynamics is necessary for peasant farmers to 200 sustainably valorise their biocultural resources and integrate socially and economically, both locally (tourism, local fairs...) and non-locally (e.g. export markets). These complementary 202 dimensions of identity and sustainability, the local and non-local, place biocultural heritage at the centre of territorial dynamics aimed at social inclusion and the preservation of common 204 welfare.

Commons are still often considered as simple resources, either tangible (water, land, seeds, etc.) or intangible (with intellectual property interests). In this view, commons differ from private or public goods because they are objects of rivalry but without exclusivity, at least within a community. However, considering that this definition obviates the social and dynamic dimensions of common goods, some authors emphasise that no common goods exist without community (Ostrom 1990). In this view, a common good is not only a resource, but also the set of rules and values mobilised by the community that care for that resource (Bollier 2015;

212 Gibson-Graham et al. 2013). For this reason, Bollier (2015) proposes replacing the word "common" with the verb "commoning" to highlight all the actions of mutual aid, negotiation,

214 communication, and experimentation mobilised for the dynamic management of shared resources. "Commoning" encompasses production, governance, culture, and personal interests

216 in an integral process. This alternative approach is enacted by responsible local communities that define their own objectives and rules in relation to their resources (Bollier 2015).

218 Aimed at meeting basic needs and rights (food, health, education, etc.), common goods naturally relate to the social inclusion of individuals and families marginalised by the market 
220 (Bollier 2015). The second assumption of this study is that socio-cultural inclusion contributes to economic inclusion because, by activating symbolic and social capital, small producers

222 generate volume and commercial capacity (FIA 2015). Here, cooperation among peasant producers appears key to building a redistributive model that improves their economic income.

224 Resilience theory, adaptive loops and panarchy

In addressing the issue of mobilising biocultural heritage in peasant communities, we used the 226 theory of resilience (Walker and Salt 2006) to explore how the social, economic and environmental components of these particular socio-ecological systems interact across time and space to determine their capacity for change towards sustainable inclusion. The adaptive loop ${ }^{2}$ model summarises the possible transformational paths of a socio-ecological system or 230 subsystem into four phases of growth $(r)$, conservation $(K)$, release $(\Omega)$ and reorganisation $(\alpha)$, the latter permitting the possible emergence of a new system (Holling 1973).

232 The position of the considered system in the four possible phases depends on the degree of organisation (connectedness) and the amount of resources (potential) accumulated in the

234 system. Connectedness and potential are defined by the ecological, economic or socio-cultural specificities of the system identified after an integrated assessment of its situation and

236 dynamics (for a detailed presentation of these concepts, see Gunderson and Holling 2002).

Adaptive loops are not 4-phase sequences repeating themselves in a deterministic way.

238 Depending on adaptability, shortcuts can be opened between different phases that allow a new system to emerge without going through the destructive release phase $(\Omega)$. In an adaptive

240 system, these shortcuts are the innovative paths to sustainability. Innovation also occurs at the end of the reorganisation phase $(\alpha)$, when weak internal control (low connectivity) allows

242 external opportunities ("chance events") to take root and open a path for unanticipated growth (r) for a renewed system.

\footnotetext{
${ }^{2}$ We use the term "adaptive loop" to avoid the connotation of deterministic recurrence of the term "cycle", originally coined by Holling (1973).
} 
244 A panarchy represents a hierarchy of adaptive loops, nested in increasing levels of organisation (or scales), that interact with each other and drive the dynamics of the entire system

246 (Gunderson and Holling 2002). Typically, a panarchy in a socio-ecological system consists of nested loops of households - the basic units of living and decision-making-, which are

248 themselves rooted in the territory and its economic activities and, beyond that, in the entire society that sets socio-demographic rules and conditions.

250 In a panarchy, different types of cross-scale interactions can be recognised, including the "revolt" connection-when the collapse of a small-scale subsystem in $\Omega$ phase propagates into

252 the surrounding, higher level, system in late $K$ phase-and the "memory" connection-through which a collapsed subsystem reorganises itself $(\alpha)$ from the resources of the surrounding,

254 higher level, system (Gunderson and Holling 2002).

Adaptive loops and resilience theory have been used to frame the dynamics of change in 256 agricultural socio-ecosystems at the individual farm, territorial or industry level (e.g. Allison and Hobbs 2004; Sinclair et al. 2014; Darnhofer et al. 2016; Slight et al. 2016), though applications

258 of a complete panarchy nesting multiple adaptive loops across scales remain rare (but see: Soane et al. 2012; Tittonell 2014) and, to our knowledge, none have considered biocultural 260 heritage issues.

General objective of the study

262 Building on previous vulnerability assessments of two participatory research projects in Chile (Baquiana project) and Bolivia (Equeco project), we used the integrative framework of panarchy

264 to identify the organisational levels, stakeholders and institutions involved in promoting local biocultural heritage for the socio-economic inclusion of peasant communities. Based on this

266 systemic vision of the complex transformations underway in two socio-ecosystems with different trajectories and purposes, we looked for the cross-scale interactions that underlie 268 them and the rationales implemented by local actors, with the aim of drawing general lessons on the conditions for inclusive sustainability based on common goods.

\section{Case 1: Lipimávida, Chile}


Socio-ecological assessment

272 Lipimávida is a locality on the Pacific coast of the Vichuquén municipality (municipalidad) in the Region of Maule, in central Chile. In 2010, according to the policy for isolated localities

274 (Gobierno Regional del Maule 2012), Vichuquén was considered the most isolated municipality in the region in a critical condition with respect to access to services, education, and capacity

276 for consumption. The earthquake and subsequent tsunami of February 2010 devastated Lipimávida. Subsequently, this exiguous coastal area-inhabited although not constructible

278 according to civil security norms - saw the construction of a new village on higher terrain in the locality, while buildings and chalets continued to be built in unauthorised coastal areas.

280 The locality is a seaside resort comprised of long beaches and a settlement of residents historically dedicated to family agriculture and the production of woven and ceramic

282 handicrafts made by traditional local techniques. Its location at the end of the J60 coastal route gives Lipimávida a singularity and isolation, making it attractive for tourists looking for quiet

284 seascapes and a pleasant Mediterranean climate.

Among the gastronomic attractions of the locality is the papaya, whose "trees" are part of the 286 local landscape in patios and orchards. The women prepare preserves, jams and desserts that, together with the seafood and peasant cuisine, characterise the Lipimávida table. Another crop 288 that stands out in the memory of the residents is quinoa, whose local ecotype differs from the Bolivian ecotypes, showing less cold tolerance (Bertero 2001) and smaller grains (Bertero et al.

290 2004). Specific to the Pacific littoral, the local quinoa was domesticated by ancestral populations of the central and southern coastal areas of Chile. In Lipimávida, older people 292 remember that quinoa's annual harvest ensured food for winter (Cubillos-Celis et al. 2018). They can still describe the practices of sowing, harvesting, and post-harvesting, in particular the 294 sorting, cleaning and de-saponification of the grains. As in other regions (Laguna 2011; Winkel et al. 2012), the time and effort required for these tedious post-harvest processes, usually 296 carried out by women in charge of cooking family meals, are the main reasons for the decline of quinoa in the local diet, making it a locally underused resource. Still, with the media attention recently given to quinoa as a superfood, inhabitants of these rural coasts are beginning to 
recover it as part of their traditions, seeing an opportunity to improve and diversify their family incomes.

At the scale of the Maule region, massive fast growing forest monocultures, pollution, and depletion of water and arable land resources, degradation of rural and urban landscapes, drought and wildfires are all associated with an economic and social model that destroys the

304 local natural and cultural heritage in the context of an unprecedented "megadrought" event (Garreaud et al. 2017). In 2017, the region experienced the worst wildfires in the last 40 years

306 (CONAF 2017). However, several initiatives reflect a growing awareness of socio-environmental issues, as illustrated by the architectural restoration of the heritage village of Vichuquén after the 2010 earthquake and the local agreement on watershed management implemented since 2017 by the National Agency for Sustainability and Climate Change (ASCC 2017).

In Lipimávida, despite an institutional and political context promoting individualism through elective democracy, generalised private land property, and a neoliberal economy, the vitality

312 and cultural identity of local associations maintain a high degree of social cohesion among members. Also noteworthy in this isolated community, some people have significant

314 experience of exchange with foreign countries, in the marketing of papaya to Belgium or the sale of handicrafts in several European countries. These successful experiences in marketing

316 high quality food and handicrafts proved valuable for the launch of a pilot project on local biocultural heritage.

The Baquiana Project implementation

In June 2017, the Baquiana research team initiated a collaboration and exchange of knowledge and experience with a focus group of a dozen residents (11 women, 1 man), all small farmers or artisans. Then, 13 meetings with an average attendance of 10 people, and 14 individual interviews were realised during the 2017-2018 period. From the beginning of this participatory process, the researchers sought to articulate the interests, positions and wishes of the focus group with regional and local state and market actors. This was possible thanks to the support of the Vichuquén municipality, where both the Mayor and professionals of PRODESAL (Local 
Development Program) demonstrated flexibility in their annual programs to host this initiative, providing time, tools and socio-technical knowledge.

328 Focusing on the production of quinoa, the preliminary assessment study established the patrimonial character of this product in the area and its potential for the economic inclusion of peasant families (Cubillos-Celis et al. 2018). A complementary study examined the social dynamics within the group of peasant actors involved in the co-construction of the pilot project associated to the participatory research (Miño-Baes and Viedma-Araya 2019).

In the course of the participatory concertation, the initial focus on quinoa suggested by researchers was challenged and reoriented towards the valorisation of a mix of traditional food and artisanal products of biocultural resources. In addition, local actors expressed that, although most did not cultivate quinoa, their problem was not the "rescue" of the crop, which could be bought from other communities and particularly from the neighbouring region of O'Higgins (Lacoste et al. 2017; Núñez and Bazile 2009). Rather, in a meeting with an expert in quinoa threshing and de-saponification, they became convinced that cleaning the grain is a complex process and that it was better to buy quinoa from other producers. Similarly, after a participatory workshop with an expert in the co-design of agricultural development projects, they felt that for them, the innovation of producing quinoa as a vegetable (Sáez-Tonacca et al. 2018) was still premature and risky. Instead, they saw a promising opportunity in this expert's proposal to activate local production and human capacities through short value chains. The pilot project "Lipimávida Heritage Fair" was then co-constructed by researchers and local stakeholders with the aim of promoting the local biocultural heritage by combining agricultural and craft products in a unique commercial offering that showcased the knowledge and skills of the inhabitants of Lipimávida.

After opening in January 2018, the heritage fair has been operating regularly, not just in the

350 summer season but also on all dates when tourists are received. Members of the group are engaged in a business that matches their interests and possibilities, offering fresh and

352 innovative products that are affordable to the diverse public visiting them.

\section{Case 2: Salar de Uyuni, Bolivia}


The observations and data that follow describe the situation in the region with the highest commercial production of quinoa in the world between 2007 and 2010, as analysed in the framework of the Equeco project. Winkel et al. (2016) present a detailed analysis of this case, and here we will only address salient points that add new insight into the issues of biocultural heritage and collective action.

The study area is located in the southern highlands of Bolivia, on the banks of the Salar de Uyuni, where plains at 3,600 meters above sea level alternate with volcanoes that reach to more than 6,000 meters above sea level. This extreme environment of high desert has been occupied for millennia by agropastoralists that raise camelids and cultivate quinoa and potatoes 364 (Cruz et al. 2017).

Despite its extreme geographic conditions, this high altitude desert was traditionally connected to the Andean "archipelago" (Murra 1984). For millennia, commercial caravans allowed local populations to manage resources of diverse ecosystems, exchanging goods such as salt, minerals, quinoa, wool and meat from the Salar highlands for corn, coca, cloth, etc. from the Andean valleys and the Pacific coast. Over time, this ancestral subsistence strategy has been complemented by temporary migration for work in mining, agriculture and various activities in more or less remote cities.

372 Land tenure, characterised by the common use for grassland and family usufruct for cropland (Vassas-Toral 2015), confers a certain social equity in the access to land while protecting the communities - through the absence of a land market - from the risk of excessive concentration of land or outsiders' land-grabbing (Winkel et al. 2016). Common pastures are generally located on plains, while family croplands were traditionally located on slopes, a disposition reflecting ancestral ecological knowledge regarding the distribution of frost risks in mountain areas ${ }^{3}$ 378 (Pouteau et al. 2011). In this desert area, each quinoa harvest results from a biennial dry fallow

\footnotetext{
${ }^{3}$ Due to its higher density, cold air drains to the lowlands at night thus increasing the risk of frost there while slopes remain less exposed.
} 
cycle and thus represents a doubled land area: the current cultivated field, plus the ploughed fallow waiting for the next year's crop. These specificities of community land tenure and biennial dry fallowing, which protect communities from land-grabbing and allow commercial production without irrigation, are central to understanding the sustainability of rainfed production in the region.

384 In the early 1970's, after massive job cuts in the mining and public sectors due to structural adjustment plans, smallholder families from indigenous communities of the Salar of Uyuni 386 initiated the expansion of quinoa as a cash crop in response to increasing demand for quinoa in neighbouring Peru, a traditional importer of Quinoa Real-the local quinoa ecotype of the Salar region. This initial phase of commercial production was favoured by a donation of tractors from a Belgian NGO (Laguna 2011) and by Peru's policy of supporting Andean food (Kerssen 2015); a case of "chance events" as coined by Gunderson and Holling (2002). This expansion of commercial quinoa production sparked a strong territorial dynamic that included: the partial mechanisation of quinoa crops, which required converting much of the flat grasslands-the only spaces accessible to tractors-into croplands; and the replacement of the distant and prolonged emigration with various forms of seasonal mobility towards nearby urban centres that became the principal places of residence of most quinoa producers.

In the observation period, the study area was populated by approximately 12,000 families of quinoa producers, most of them of Aymara or Quechua origin with a strong cultural identity (Vassas-Toral 2015; Vieira-Pak 2015). This factor of social cohesion is also observed in the rotating system of community obligations for the management of roads, local festivals, school, etc. For each producer, complying with these community obligations and paying local taxes guarantees the right to access the usufruct of the communitary land, even if his residence in the community is intermittent (Vassas-Toral 2015).

In relation to this lively tradition of self-management and participation in collective life, local 404 populations have demonstrated their organisational and negotiating capacity when they formed, with the encouragement of European NGOs, powerful associations of family producers. 
in 1974) and ANAPQUI (Asociación Nacional de Productores de Quinua, founded in 1983) encourage the production, transformation and marketing of quinoa, including export to new niche markets with organic and fair-trade certifications (Laguna 2011; Tschopp et al. 2018).

410 As a corollary of their success in the commercial production of quinoa, local producers have promoted a rebalancing of regional territorial development, investing their new income not so

412 much in rural communities but rather in the neighbouring cities of Salinas de Garcí Mendoza, Llica, Uyuni, Challapata, Oruro, etc. Compared to the rural sector, the provision of health 414 services, education, electricity, water, transport, and connection in the urban sector allows for improved training and the professionalisation of their children (Vassas-Toral 2015). Taking

416 advantage of their dual residence between rural and urban areas, most families combine two or more activities in agriculture and livestock, handicraft, transport, commerce, mining, urban 418 employment, tourism, etc. (Vassas-Toral 2015). Among their agricultural activities, families conserve a self-consumption production of quinoa and potatoes, while the breeding of camelids and sheep-unprofitable and poorly compatible with urban residency-has diminished. Handicraft (wool) and tourism activities (accommodation, driver-guide) remain 422 marginal. Non-agricultural income offers a guarantee against the volatility of quinoa prices, which peaked in January 2014 (approx. 6,000 USD/ton) and then stabilised at around 1,2004241,600 USD/ton.

While the assessment of peasant family income remains uncertain, a survey of 36 households in 426 the study area in 2007 (when quinoa was paid to the producer at about 750 USD/ton) reveals the great disparity present within a single community, with incomes ranging from 200 to 18,000 428 USD per year (Winkel et al. 2016). This disparity in family income reflects differences in social status (e.g. young single mothers vs. extended families) and inequalities in economic power, 430 both of which influence access to land since the inheritance of land usufruct in the region is generally patrilineal and the extent of cultivated land depends on the ability of each producer

432 to assume the cost of hiring a tractor driver to plough and sow the land.

With regard to the regulation of access to land, customary rules controlled by communities and 434 indigenous authorities mix with national laws adopted by the central government. More 
specifically, agricultural production is governed by local consensual and collective norms, which compete with food certification controls and foreign trade regulations. Low acceptance rates and the lack of practical implementation result in the inconsistent application of most of these rules across the region.

The Equeco Project implementation

440 The Equeco project was launched in 2007, more than three decades after the start of quinoa export production in the Salar de Uyuni region, a process that can be dated from the arrival of

442 the first agricultural tractors in late 1969 (Laguna 2011). Questioning the sustainability of a process that has been going on for more than 30 years, project researchers examined the social

444 and environmental history of local quinoa production (see Winkel et al. 2014, 2015, 2016, for more details). Focus groups were comprised of quinoa producers from various rural 446 communities around the Salar de Uyuni as well as the NGO AVSF ("Agronomists and Veterinarians without Frontiers"), involved in a regional project for the sustainable 448 management of local agro-pastoral systems.

The participatory methodology of the project was based first on participant observation, where researchers immersed themselves in the daily life of local producers for several months. Based on this initial assessment of the local situation, role-playing workshops followed by group

452 analysis sessions were held in the communities to discuss with participating producers what happened during the game and to analyse the similarity between game and reality (Vieira-Pak

454 2015). As regards local development, researchers issued recommendations for local stakeholders (producers, authorities, NGOs...) particularly concerning the consensual renewal 456 of communal norms of land access and use (AVSF 2010). On an international scale, researchers accompanied the renegotiation process between producer organisations and FairTrade

458 International on the new fair-trade certification standards for quinoa (Salliou 2011).

\section{Adaptive loops and panarchy}

460 Case 1: Lipimávida (Chile) 
Returning to the case of Lipimávida, three levels of analysis of the ongoing innovation process emerged from the study: the group of food and handicraft producers, the tourism activity in the locality of Lipimávida, and the socioeconomic context of the Vichuquén municipality.

First loop: quinoa and handicraft producers

The concertation process among the local participants in the Project resulted in the decision to establish a new fair of heritage products in the community, with the objective of allowing its participants to market their handicraft, food, and local products in their own territory and without intermediaries. In its organisational phase, the fair group began with 12 members, maintaining oral agreements for its regulation, sustained by the bonds of trust that existed among the participants. This group of a few people did not need a large organisation or a long dialogue to start operating. To ensure a sufficient number of potential clients, the group

472 decided to hold the fair on Sundays during the summer season (January, February). Once the offer of products, the type of activity, and its frequency were agreed upon, the members of the

474 fair, with the help of the Project facilitators, were able to mobilise external support from the municipality, rural development services (PRODESAL) and from the parish. Through this, they

476 obtained the official authorisation to occupy public space, publicity for the inauguration of the fair, and the use of a parking lot for their clients.

478 This brief analysis (see Cubillos-Celis et al. 2018, and Miño-Baes and Viedma-Araya, 2019, for a complete description of the process) highlights that the local producer group is in an initial phase, organised around a project of local fair with a well-defined orientation: promoting craft and food products from their biocultural heritage. Yet, this producer group has chosen to

482 maintain a diversified offer and, up to now, its few members have decided to govern themselves by simple oral agreements. There is no evidence of extreme product specialisation, 484 high investment in economic or work resources, organisational complexity or connectivity that could hinder the adaptability of the group and compromise the viability of the heritage fair project. For all these reasons, the current phase can be referred to as an initial $(r)$ growth phase. 
Since the beginning of the 2000 's, the tourism sector in Lipimávida has grown consistently. The number of tourist establishments increased from 6 in 2004 to 70 in 2018, with a combined accommodation capacity of more than 400 people. In this locality with only one hotel, this development is mainly due to the decision of local residents to convert part of their agricultural land for the building of cabins rented to tourists on weekends or for longer holidays.

494 The locality has 6 restaurants that offer a variety of menus with fish, seafood, quinoa, and papayas. Several stores sell fresh and processed food products, where quinoa and papaya stand 496 out. The direct sale of fresh vegetables, medicinal plants, eggs and honey, as well as local handicrafts, is also important in the residents' homes. In fact, handicrafts are an essential 498 component of the local tourism market, with exceptional production in clay (greda blanca) and sheep's wool, spun locally and coloured with natural dyes then transformed into highly valued 500 fabrics, some of which are sold in European markets.

Despite the high potential for tourism in Lipimávida, the sector shows signs of vulnerability. The

502 town is located on a dead-end road, connected to other coastal cities by a single route (J-60) that is rapidly saturated in the peak season. This causes numerous traffic jams repeatedly 504 reported by the local press. In addition, in the Maule region in general and in the town of Lipimávida in particular, water scarcity seriously affects the supply of drinking water and 506 sewage services. The seasonal influx of tourists into the region exacerbates this problem. Tourist constructions directly bordering the ocean coastline seem vulnerable because they 508 violate building regulations in seismic risk areas.

Local tourism in Lipimávida can be characterised as an advanced $(K)$ phase of the adaptive loop 510 since many indicators reveal: the concentration of financial and social resources (potential axis) in tourism-related activities (accommodation, restaurants, shops and crafts); and strong

512 pressures (connectedness axis) on the local road, land, and water resources, which present risks for tourism development and the commercial potential of the territory.

\section{Third loop: communal socio-economic dynamics}


In administrative and political terms, Lipimávida depends on Vichuquén that supports different types of projects aimed at contributing to the development of the territory and the well-being of its inhabitants. Crucial for Vichuquén and the surrounding municipalities, in 2017 the National Climate Change Agency initiated a "Voluntary Agreement" for the management of water resources of the Llico, Vichuquén, Torca, Tilicura, and Agua Dulce watersheds. Through a participatory process, a public-private alliance has been formed bringing together 24 organisations with the participation of public administrations, civil society organisations,

522 cultural groups, the scientific academy, the Army and private companies. The projects promoted by the Voluntary Agreement address diverse areas such as environment, agriculture 524 and industry, education, health, tourism and culture, so as to coordinate efforts and resources and integrate different actions that contribute to the sustainable development of the basin in

526 the face of climate change, and the foreseeable decrease in water resources. Although some projects are already underway, others have not yet begun and all options remain open, because

528 the Voluntary Agreement is an evolutionary process in which new initiatives may be presented.

Due to the active coordination (connectedness) of multiple projects in different fields, and no sign of exhaustion of social and financial capital (potential), the socio-economic sector at the communal level can be considered in a dynamic $(r)$ phase of its adaptive loop.

\section{Integrating the adaptive loops in a panarchy}

In the end, the integration of the three adaptive loops shows a tourism subsystem in advanced

$534(K)$ phase, prevailing over any other economic activity, and vulnerable not only to occasional seismic hazards but also to the ongoing overexploitation of land, water and infrastructure resources. Yet, the subsystems immediately below and above, both in a $(r)$ phase, show a responsible commitment to paths of sustainability (communal loop) and socio-economic diversification and autonomy (producers' loop), all favourable to managing the vulnerability of local tourism activities (Fig. 1, case 1). 


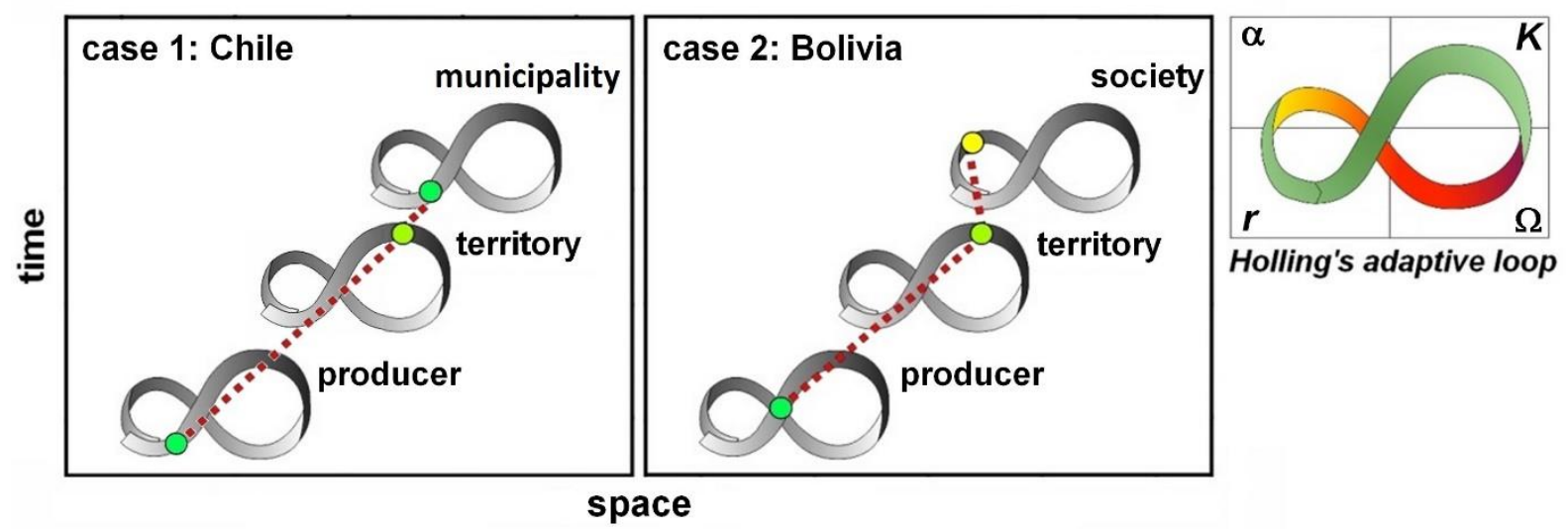

542 Fig. 1. Schematic representation of the panarchies of the two study cases. For each case, three nested subsystems are hierarchically scaled and their respective positions in Holling's adaptive 544 loops are symbolised according to the right-hand insert.

546 Case 2: Salar de Uyuni (Bolivia)

First loop: quinoa producer families

548 In the 1980's, Bolivian quinoa growers opportunistically responded to increased demand for gluten-free, protein-rich, organic food in North America and Europe. These new markets, often 550 labelled fair-trade, did not replace the Peruvian market which remained open to unofficial trade of conventional (non-organic) quinoa (Gandarillas et al. 2015; Laguna 2011; Rojas 2011). Local

552 quinoa producers thus occupy a diversity of niches in the growing quinoa market, but did not specialise in this unique production. While only a few continue to raise llama and sheep-an

554 activity with low economic profitability, incompatible with temporary migration -, most maintain a seasonal rural/urban mobility that allows for off-farm activities in neighbouring

556 cities where producer families live almost year-round (especially those with children in school). This strategy of on-farm/off-farm pluriactivity involving different family members results in 558 much diversified household economies (Laguna 2011; Vassas-Toral 2015; Ofstehage 2011, 2012; Vieira-Pak 2015). 
560 Considering the income of quinoa (potential) and the connection to market niches (connectedness), the household economy of quinoa producers shows a situation of multiple

562 trajectories between the growth $(r)$ and conservation $(K)$ phases. Resolutely engaged in commercial production, local families still maintain flexibility in their activities, thus avoiding

564 complete specialisation in a profitable but risky business. This flexibility is reflected in partial "back loops" when quinoa producers chose to alternate between multiple on- and off-farm

566 activities, and multiple market niches from conventional to certified quinoa, moving opportunistically from one trajectory to another (Vassas-Toral 2015; Ofstehage 2011, 2012).

568 Second loop: community territory

The agricultural landscape of the Salar region has been profoundly modified by the change in

570 land use from pasture to crop fields, with almost all of the mechanisable lowlands now converted to quinoa fields. More than unclear and controversial land degradation (Walsh-Dilley

572 2013; Winkel et al. 2012), it is the land area converted to quinoa crops that appears as the most reliable indicator of the local agroecosystem having reached its maximum carrying capacity, 574 with a significant homogenisation of the landscape and virtually no more space available for new crops.

576 The adaptive loop of the community territory thus appears to be trapped in an advanced conservation phase $(K)$ with vast quinoa monocultures resulting in minimal landscape diversity

578 (maximum field connectivity) and maximum available land capital (potential) already converted into cropland.

Third loop: socioeconomic context

The socio-economic analysis of the Salar region highlights contradictory characteristics in local population dynamics, with the national census indicating a continuous population loss whereas recent studies suggest a "re-peasantisation" of the region (Kerssen 2015; Vassas-Toral 2015). In 584 fact, commuting between rural and urban areas remains the current livelihood strategy for the majority of the population, which implies a continuous reorganisation of household and economic activities on a monthly (sometimes weekly) time scale. 
The strategy of double rural/urban residence has implications for the norms of access to and use of agricultural resources, since compliance with these norms allows double residents to claim land access rights in their community of origin. Yet, here too multiple rules enacted at different levels of organisation (community, nation, international organisations, food industry) are accumulating, and continually rearranged and reinterpreted.

592 Thus, continuous adjustments in population dynamics (social potential) and land resource management (normative connectedness) indicate an adaptive loop of the social system located

594 in a $(\alpha)$ phase of prolonged reorganisation, with temporary emigrants crossing returnees, and with multiples_sometimes unimplemented-land management rules.

Integrating the adaptive loops in a panarchy

In total, the scaling of the three adaptive loops shows a territorial subsystem in a vulnerable $(K)$ phase, but without any apparent risk of a "revolt" type connection since the underlying system is in intermediate $(r)$ phase, with quinoa producers' families maintaining a risk-coping strategy of mobility and pluriactivity on-farm and off-farm. At a higher level, the $(\alpha)$ phase characterising the socio-economic context leaves open the possibility of multiple initiatives to tackle the issue 602 of the vulnerability of the territorial system (Fig. 1, case 2).

\section{Discussion and conclusion}

604 Since localities are at the crossroads of daily actions of local stakeholders and planned interventions of external entities, it is not surprising that their territories emerge from the panarchy analysis as the places where the vulnerability of local socio-ecological systems concentrates. A more interesting result is to identify strengths and bottlenecks at adjacent scales to address issues at this crucial organisational level. We have done this by paying particular attention to "commoning" processes valuing the biocultural heritage in the perspective of an inclusive peasant agriculture.

Commoning to get included 
612 The two study cases illustrate how the inclusion of peasant farming through heritage products operates simultaneously in two directions. First, it operates "inwards", with the inclusion of

614 individual peasants and artisans in local organisations that allow them to act for common objectives, i.e. "commoning" in Bollier's terms (2015). It also operates "outwards" with the

616 recognition of peasants and artisans and their productions by a range of external socioeconomic actors: authorities, social and territorial development agents, processors and

618 marketers, gastronomic promoters, media and, finally, consumers.

"Inwards", social inclusion resulted from collaborative processes of decision making, production 620 and valorisation of biocultural goods, with the participation of marginalised people, like women (case 1) or smallholders (case 2). Cooperation helps social and economic inclusion through the

622 co-construction of new aspirations and identities, such as initiating and managing short value chains ${ }^{4}$ for diverse heritage products (case 1 ) or for an ancestral ecotype of quinoa, Quinua

624 Real, emblematic of a vast territory (case 2). To individuals and families with little economic power, collective action thus offers new social roles that embody cultural values and imply both

626 their responsibility and their rights (Bollier 2015). In addition, the relationships that bind communities to their trade establish a boundary around their activity, which gives it a form of 628 encloseability, considered by Colloredo-Mansfeld (2011) as necessary to govern common goods and protect them from free riders. The two case studies belong to the category of social

630 innovations resulting from bottom-up, multi-stakeholder and inclusive collective processes that emerge from territories to respond to aspirations for change and local social needs (Faure et al.

632 2018).

"Outwards", more than just commercial spaces, the local fair (case 1) and the international 634 niche markets (case 2) become spaces for producers to meet consumers directly and for the rest of society to recognise their products.

636 The cooperation and self-organisation of the producers are the pillars of "commoning", which can be satisfied with an informal but effective grouping (case 1) or form powerful national

\footnotetext{
${ }^{4}$ Remember that "short value chain" does not refer to the geographical distance between producer and consumer, but rather to the reduced number of intermediaries that separate them in the value chain.
} 
638 associations (case 2). Cooperation brings autonomy and, usually, involves a form of selfmanagement that goes beyond the simple need to generate commercial value (Lucas et al.

640 2016). Solidarity and social inclusion, identity and cultural recognition are also key values for the sustainability of community groups (Lacoste et al. 2017).

642 In a broader perspective, both case studies demonstrate the importance of local action for the governance of biocultural resources, thus corroborating the potential for efficiency and 644 resilience of local self-organisation compared to centralised governance of natural resources (Ostrom 1990; Tittonell 2014; Tschopp et al. 2018).

646 Local experiences of "commoning" can be difficult to replicate as they are often based on informal networks of contacts and cooperation (Macías Vázquez and Alonso González 2015).

648 The relationship of trust gradually built between the actors can be formalised through a contract of the rights and duties of the participants, such as the renewed norms of access and use of land in case 2 (AVSF 2010). But case 1 shows that in a still incipient innovation process the lack of a formal contract does not prevent-and perhaps facilitates-joint and effective 652 action by the group.

Another key point is the mobilisation of consumers in support of producers at the other end of 654 the value chain. In the face of attempts to capture cultural value by exogenous actors, it seems essential to maintain local social control (on the part of producers) and non-local control (on

656 the part of consumers) over the material capital of natural resources and products, but also over the collective symbolic capital of knowledge, norms, images, etc. (Macías Vázquez and

658 Alonso González 2015). This objective of social control over heritage products does not mean that the community of producers withdraws into itself: at the other end of the value chain, 660 citizen organisations concerned about the quality of their food, authenticity, social justice and the sustainability of their modes of consumption can effectively support the orientations of 662 local producers (e.g. through militant fair-trade associations or community-supported agriculture). Sustained public participation in the heritage fair in case 1 and the engagement of 664 fair trade organisations with quinoa producers in case 2 illustrate the common interest and 
objective agreement between actors at both ends of the value chain, which creates a "civic space" that goes beyond mere market exchanges (Colloredo-Mansfeld 2011).

It has been claimed that without support from state technical agencies, small producers cannot

668

670

672

674

676

678 access high-value markets (FIA 2015). However, the two cases presented here demonstrate that innovations based on the commons do not always require the intervention of centralised entities. The greater efficiency of local entities in the management of territorial resources has been emphasised by Ostrom (1990) to justify self-governance over these resources. The possibility for marginalised farmers to integrate the market for their own empowerment and establish alliances different from those recommended by external agents (government, NGOs, etc.) is an option that can be as innovative and a form of resistance to the "command-andcontrol" system (Cox 2016). However, there may also be abuses of power games or private interests at the local level, which encourages reflection on how to maintain control over individual or local actors in order to preserve the general interest. In case 2, this precaution led to the consensual renewal of communal norms to control the usurpation by a few of common pastures to convert them into crops with private usufruct (AVSF 2010).

In both cases, and regardless of their degree of formalisation, the new social organisations began with the smallest possible unit: grouping of individual producers (case 1) or an indigenous village community (case 2 ). This guaranteed the autonomy and control of local actors over the new norms to which they would be subject (Ostrom 1990).

In economic terms, the two cases we analysed show that the inclusion of family agriculture through artisanal products and heritage foods can operate by the construction of short value chains both local (case 1) and international (case 2). By distributing added value more equitably, short value chains increase the autonomy of producers while favouring agroecological transition (Lucas et al. 2016). This is illustrated in case 2 by the intense work of renewing the community norms for the sustainable use of territorial resources, the result of raising stakeholders' awareness of the ecological and social challenges of the changes underway in their territory. 
692 As a marketing strategy, short value chains often correspond to niche markets oriented towards the product (biocultural good of quality with identity) and the consumer (tourist in case 1, eco-

694 responsible consumer in case 2), rather than towards conventional distributors, who cling to criteria of volume and margins rather than quality, social justice, authenticity, or mitigation of

696 environmental damage. In this short value chain strategy, agrotourism offers local producers a particular opportunity to value their biocultural heritage within their own territory (Bazile et al.

698 2014; Núñez and Bazile 2010).

Key features of a "valuable" biocultural heritage

700 The two cases presented show that "valuable" heritage goods are products that combine local identity and the general interest, or, in other words, that unite tradition and innovation. The

702 general interest and innovation around quinoa respond to the growing concerns in global society about issues of nutrition and health, economy and environment, globalisation and social 704 justice. Regardless of the size of the target market, in both cases, local actors have been able to respond to these concerns which, essentially, consist of finding quality products with an identity 706 that convinces consumers that their purchasing act benefits the common biocultural, social or environmental heritage. The identitarian and traditional dimensions of heritage goods are

708 nourished by the affective relationship that local producers - generally inhabitants or natives of rural areas-maintain not only with their territory (Hinds and Sparks 2009) but also with each

710 other through ties of kinship or friendship (Laguna 2011; Vassas-Toral 2015; Vieira-Pak 2015). Whether consciously or not, this affective symbolic value is integrated into the price that the

712 consumer is willing to pay, generating a positive circle between market, social ties, and biocultural heritage. The strategies of local actors to valorise and commercialise their

714 biocultural goods are then oriented according to these values and expectations of society in general. This process illustrates how simultaneously managing collective and individual

716 interests at both ends of the value chains can help to resolve the ambivalence of marketing biocultural commons (Colloredo-Mansfeld 2011).

718 Territories, between local identity and non-local connectivity 
In a territorial perspective, the inclusion of peasant agriculture is established under two complementary realities: the anchoring of family producers in their lands of origin even if, as in case 2, families maintain a double rural/urban residence; and a flow of resources, people, 722 goods and information from the "outside" to the productive territory, which is then integrated into new exchange networks, making its heritage known abroad and reinforcing its connectivity 724 to the "outside".

In case 2, the anchoring and permanence of families in communities is conditioned by the 726 tension between their access to better basic services and their active control over the access and use of territorial productive resources. This tension is resolved by replacing emigrationoften long and distant-by a new form of urban/rural mobility within the region that allows compliance with communal obligations and access to land (Vassas-Toral 2015). In centralised countries, as in case 1 , this communal control of territorial resources poses the challenge of deconcentrating power and resources of state institutions.

732 For heritage resources to contribute to the inclusion of family farming, the territorial anchoring must also value a local identity - traditional or innovative-that allows for the elaboration of a 734 story or an image to be disseminated abroad (Annes and Bessière 2018). In this story or image, the territory is highlighted as a source of authentic (made by the inhabitants themselves, not by

736 industrial processes), natural (coming from the ocean, the mountains, the desert, all spaces a priori without contamination...), healthy (of high nutritional value, without chemical additives),

738 aesthetic and culturally embedded products (Colloredo-Mansfeld 2011). In case 1, these symbolic values motivated from the start the producers who were relying on their successful

740 experiences with high-quality papaya and handicrafts. For quinoa, locally an underused resource, the heritage value of its local production and use still needs to be established with 742 more evidence. A first step would be through culinary innovation to generate socio-cultural identity and strengthen the territorial anchorage of peasant agriculture. By betting on local

744 gastronomy and tourism, it is possible to promote biocultural heritage products without having to look for distant markets, which is beneficial for the autonomy of emerging groups of small 746 producers (FIA 2015). In case 2, after 40 years of "generic" quinoa production and a growing 
competition from Peru, the promotion of Quinoa Real's identity is now the basis of a denomination of origin process (Ofstehage 2011; Soraide-Lozano 2011). Yet, apart from the difficulties for peasant farmers to get into formal certification agreements (Colloredo-Mansfeld 2011), a denomination of origin may be inappropriate in the current configuration of the export market where differentiating one Bolivian ecotype from another in Peru does not motivate the

752 final consumer-European or North American - interested in the organic, healthy, or even fair trade nature of the product, but not its geographical origin (Böhm 2016). Here, the

754 geographical distance between producers and consumers seems to be an obstacle for the latter to appreciate the biocultural heritage of a distant and unknown territory, especially in the case

756 of a food such as quinoa, which is consumed marginally compared to tea and coffee, for example, whose globalised consumption is accompanied by a search for a diversity of origins.

758 Solving these bottlenecks requires virtuous networks between conscious and organised citizens, and a socially and ecologically responsible market, i.e. new terms of the social contract to take into account local requirements in globalised scenarios (De Schutter 2011).

Overall, innovations based on biocultural heritage-whether creative in the case of a new heritage fair or essentially adaptive in the case of sustainable export production-have made it possible to change the local reality of small farmers without hindering existing activities, which seems to guarantee their acceptability and social and economic viability in the medium and long term. In particular, their consensual and progressive nature has made it possible to promote inclusive changes that contribute to good living together.

\section{References}

768 Allison, H. E., and R. J. Hobbs. 2004. Resilience, adaptive capacity, and the "Lock-in Trap" of the Western Australian agricultural region. Ecology and Society 9: 3. URL: http://www.ecologyandsociety.org/vol9/iss1/art3/.

Annes, A., and J. Bessière. 2018. Staging agriculture during on-farm markets: how does French

772 farmers' rationality influence their representation of rurality? Journal of Rural Studies 63: 34-45. URL: https://doi.org/10.1016/j.jrurstud.2018.1007.1015. 
774 ASCC (Agencia de Sustentabilidad y Cambio Climático). 2017. Acuerdo voluntario para la gestión de la cuenca Llico, Vichuquén, Torca, Tilicura, Agua Dulce y sus afluentes. Santiago, Chile:

776 Agencia de Sustentabilidad y Cambio Climático. 28 p. URL:

http://www.agenciasustentabilidad.cl/pagina/acuerdos_voluntarios_para_la_gestion. Accessed

77815 October 2019.

AVSF (Agrónomos and Veterinarios sin Fronteras). 2010. Pauta metodológica para la

780 elaboración de las normas comunales y sus planes de cumplimiento. La Paz, Bolivia: Agrónomos and Veterinarios sin Fronteras. URL: https://www.avsf.org/es/posts/633/full/. Accessed 15

782 October 2019.

Barrientos, E., F. Carevic, and J. Delatorre. 2017. La sustentabilidad del altiplano sur de Bolivia y

784 su relación con la ampliación de superficies de cultivo de quinua. Idesia (Chile) 35: 7-15. URL: http://dx.doi.org/10.4067/S0718-34292017005000025.

786 Bazile, D., E. Martínez, J. Negrete, M. Thomet, E. Chia, H. Hocdé, and L. Nuñez. 2014. Biocultural heritage: Quinoa as an important resource to be maintained through tourism experiences for

788 food security in the face of climate change. Tourism, Leisure and Global Change 1:1-16. URL: https://www12.nau.edu/nabej-p/ojs/index.php/igutourism/article/view/313.

790 Bedoya-Perales, N., G. Pumi, A. Mujica, E. Talamini, and A. Domingos Padula. 2018. Quinoa expansion in Peru and its implications for land use management. Sustainability 10: 532. URL:

792 https://doi.org/510.3390/su10020532.

Beling, A. E., J. Vanhulst, F. Demaria, V. Rabi, A. E. Carballo, and J. Pelenc. 2018. Discursive

794 synergies for a 'Great Transformation' towards sustainability: pragmatic contributions to a necessary dialogue between human development, degrowth, and Buen Vivir. Ecological

796 Economics 144: 304-313. URL: https://doi.org/10.1016/j.ecolecon.2017.08.025.

Bertero, H. D. 2001. Effects of photoperiod, temperature and radiation on the rate of leaf

798 appearance in quinoa (Chenopodium quinoa Willd.) under field conditions. Annals of Botany 87: 495-502. URL: https://doi.org/10.1006/anbo.2000.1362 
800 Bertero, H.D., A.J. de la Vega, G. Correa, S.E. Jacobsen, and A. Mujica. 2004. Genotype and genotype-by-environment interaction effects for grain yield and grain size of quinoa

802 (Chenopodium quinoa Willd.) as revealed by pattern analysis of international multienvironment trials. Field Crops Research 89: 299-318. URL:

804 https://doi.org/10.1016/j.fcr.2004.02.006

Blay-Palmer, A., R. Sonnino, and J. Custot. 2016. A food politics of the possible? Growing 806 sustainable food systems through networks of knowledge. Agriculture and Human Values 33 (1):27-43. URL: https://doi.org/10.1007/s10460-015-9592-0.

808 Böhm, F. 2016. The grain of the gods against poverty: approaching the quinoa value chain in Bolivia and Peru with inclusive business models. MSc thesis in Global Business and

810 Sustainability. Rotterdam, The Netherlands: Rotterdam School of Management..

Bollier, D. 2015. Commoning as a transformative social paradigm. The Next System Project, an

812 initiative of the Democracy Collaborative. Washington DC, USA. URL:

https://thenextsystem.org/commoning-as-a-transformative-social-paradigm. Accessed 15

814 October 2019.

Castaldo, S., F. Perrini, N. Misani, and A. Tencati. 2009. The missing link between corporate

816 social responsibility and consumer trust: The case of fair trade products. Journal of Business Ethics 84: 1-15. URL: https://doi.org/10.1007/s10551-10008-19669-10554.

818 Chakrabarti, S. 2014. A critique of inclusive growth: problems of modernization of agriculture. World Review of Political Economy 5:372-391. URL:

820 https://doi.org/310.13169/worlrevipoliecon.13165.13163.10372.

Colloredo-Mansfeld, R. 2011. Work, cultural resources, and community commodities in the

822 global economy. Anthropology of Work Review 32: 51-62. URL: https://doi.org/10.1111/j.15481417.2011.01058.x.

824 CONAF. 2017. Situación diaria de incendios forestales. http://www.conaf.cl/situacion-nacionalde-incendios-forestales/. Accessed 15 October 2019. 
826 Contreras, R.; E. Krivonos, and L. Sáez. 2014. Mercados locales y ferias libres: el caso de Chile. In Agricultura familiar en América Latina y el Caribe: recomendaciones de políticas, eds., S.

828 Salcedo, and L. Guzmán. Santiago, Chile: FAO. URL:

http://www.fao.org/docrep/019/i3788s/i3788s.pdf.

830 Cox, M. 2016. The pathology of command and control: a formal synthesis. Ecology and Society 21: 33. URL: http://dx.doi.org/10.5751/ES-08698-210333

832 Cruz, P., T. Winkel, M. P. Ledru, C. Bernard, N. Egan, D. Swingedouw, and R. Joffre. 2017. Rainfed agriculture thrived despite climate degradation in the pre-hispanic arid Andes. Science

834 Advances 3: e1701740. URL: http://dx.doi.org/ 10.1126/sciadv.1701740.

Cubillos-Celis, E., C.J. Poblete-Olivera, and N.O. Zavalla-Nanco. 2018. Contribución de la

836 agricultura familiar campesina a la preservación y salvaguardia del patrimonio cultural y natural de la quinoa en Lipimávida. Tesis de Grado. Curicó, Chile: Universidad Católica del

838 Maule.

Darnhofer, I., C. Lamine, A. Strauss, and M. Navarrete 2016. The resilience of family farms:

840 towards a relational approach. Journal of Rural Studies 44: 111-122. URL:

http://dx.doi.org/10.1016/j.jrurstud.2016.01.013

842 Delatorre-Herrera, J., M. Sánchez, I. Delfino, and M.I. Oliva. 2013. La quinua (Chenopodium quinoa Willd), un tesoro andino para el mundo. Idesia (Chile) 31: 111-114. URL:

844 http://dx.doi.org/10.4067/S0718-34292013000200017.

De Schutter, O. 2011. Towards more equitable value chains: alternative business models in 846 support of the right to food. New York, USA: United Nations.

Essex, J., and R. Read. 2016. To be truly inclusive, we must stop prioritising 'growth': a critique

848 of the RSA's 'Inclusive Growth Commission'. London, UK: Green House. URL:

https://www.greenhousethinktank.org/gases.html

850 Faure, G., Y. Chiffoleau, F. Goulet, L. Temple, and J.M. Touzard, eds. 2018. Innovation et développement dans les systèmes agricoles et alimentaires. Versailles, France: Editions QUAE. 
852 FIA (Fundación para la Innovación Agraria). 2015. Patrimonio agroalimentario. Innova+Agro 1: 100 p. URL: http://bibliotecadigital.fia.cl/handle/20.500.11944/1861.

854 Gandarillas, A., W. Rojas, A. Bonifacio, and N. Ojeda. 2015. Quinoa in Bolivia: the PROINPA Foundation's perspective. In State of the art report on quinoa around the world in 2013, eds. D.

856 Bazile, D. Bertero and C. Nieto. Rome, Italy: FAO, 344-377. URL: http://www.fao.org/343/ai4042e.pdf.

858 Garreaud, R. D., C. Alvarez-Garreton, J. Barichivich, J. P. Boisier, D. Christie, M. Galleguillos, C. LeQuesne, J. McPhee and M. Zambrano-Bigiarini. 2017. The 2010-2015 megadrought in central

860 Chile: impacts on regional hydroclimate and vegetation. Hydrology and Earth System Sciences 21: 6307-6327. doi: 10.5194/hess-21-6307-2017

862 Gavin, M. C., J. McCarter, A. Mead, F. Berkes, J. R. Stepp, D. Peterson, and R. Tang. 2015. Defining biocultural approaches to conservation. Trends in Ecology and Evolution 30: 140-145.

864 URL: http://dx.doi.org/10.1016/j.tree.2014.12.005.

Gibson-Graham, J.K., J. Cameron, and S. Healy. 2013. Take back the economy: an ethical guide

866 for transforming our communities. St Paul, USA: University of Minnesota Press.

Gobierno Regional del Maule. 2012. Política regional de desarrollo de localidades aisladas.

868 Región del Maule. Talca, Chile: Gobierno Regional del Maule, División de Planificación y Desarrollo Regional.

870 Grivins, M. and T. Tisenkopfs. 2018. Benefitting from the global, protecting the local: The nested markets of wild product trade. Journal of Rural Studies 61: 335-342. URL:

872 https://doi.org/310.1016/j.jrurstud.2018.1001.1005.

Gunderson, L. H., and C. S. Holling, eds. 2002. Panarchy: understanding transformations in 874 human and natural systems. Washington (DC), USA: Island Press.

Hinds, J. and P. Sparks. 2009. Investigating environmental identity, well-being, and meaning.

876 Ecopsychology 1: 181-186. URL: https://doi.org/110.1089/eco.2009.0026.

Holling, C. S. 1973. Resilience and stability of ecological systems. Annual Review of Ecology and 878 Systematics 4:1-23. URL: https://dx.doi.org/10.1146/annurev.es.1104.110173.000245. 
Ioris, A.A.R. 2016. Introduction: underscoring agribusiness failures, environmental controversies, and growing food uncertainties. In: Agriculture, Environment and Development, ed., A.A.R. Ioris. Switzerland: Springer. URL: https://doi.org/10.1007/1978-1003-1319-3225532251.

Isgren, E. and B. Ness. 2017. Agroecology to promote just sustainability transitions: analysis of a civil society network in the Rwenzori Region, Western Uganda. Sustainability 9: 1357. URL: http://www.mdpi.com/2071-1050/1359/1358/1357. 3: 215-239. https://doi.org/10.1007/s11625-008-0053-1

Kerssen, T. M. 2015. Food sovereignty and the quinoa boom: challenges to sustainable repeasantisation in the southern Altiplano of Bolivia. Third World Quarterly 36:489-507. URL: https://dx.doi.org/410.1080/01436597.01432015.01002992.

Lacoste, P., A. Castro, F. Mujica, and M. Lacoste Adunka, eds. 2017. Patrimonio y desarrollo 892 territorial. Productos típicos alimentarios y artesanales de la Región de O'Higgins. Identidad, historia y potencial de desarrollo. Santiago, Chile: Instituto de Estudios Avanzados, Universidad 894 de Santiago de Chile (USACH).

Laguna, P. 2011. Mallas y flujos: acción colectiva, cambio social, quinua y desarrollo regional indígena en los Andes bolivianos. PhD thesis in Social Sciences. Wageningen, The Netherlands: Wageningen University. URL: http://edepot.wur.nl/188049

898 Lucas, V., P. Gasselin, and J.D. Van Der Ploeg. 2016. Increasing searches for autonomy among French farmers: a starting point for agroecology? 12th European IFSA Symposium "Social and technological transformation of farming systems: Diverging and converging pathways". July 2016. Harper Adams University, Edgmond, UK. URL: https://www.harperadams.ac.uk/events/ifsa/papers/13/13.14\%20Lucas.pdf.

Macías Vázquez, A., and P. Alonso González. 2015. Managing collective symbolic capital through 904 agro-food labelling: strategies of local communities facing neoliberalism in Spain. Journal of Rural Studies 41: 142-152. URL: http://dx.doi.org/10.1016/j.jrurstud.2015.08.03. 
Miño-Baes, B.N., and M.P. Viedma-Araya. 2019. Producción sostenible de quinua en la localidad de Lipimávida: resguardando el patrimonio natural y cultural de la agricultura familiar campesina. Tesis de Grado. Curicó, Chile: Universidad Católica del Maule (UCM).

Murra, J. V. 1984. Andean societies. Annual Review of Anthropology 13:119-141. URL:

910 https://dx.doi.org/110.1146/annurev.an.1113.100184.001003.

Núñez Carrasco, L., and D. Bazile. 2009. Cultura campesina en Chile central sobre la producción

912 y consumo de Chenopodium quinoa Willd.: el caso de la comuna de Paredones provincia Cardenal Caro, región de O’Higgins. Revista de Geografía de Valparaíso 42: 87-94. URL:

914 http://www.rgv.ucv.cl/articulos/Articulo42-88.pdf.

Núñez, L.C., and D. Bazile. 2010. La ruta de la quínoa costera y sus tradiciones campesinas.

916 Anales de la Sociedad Chilena de Ciencias Geográficas: 254-260. URL:

http://www.sochigeo.cl/circulares/diez.pdf

918 Ofstehage, A. 2011. Nusta Juira's gift of quinoa: peasants, trademarks, and intermediaries in the transformation of a Bolivian commodity economy. Anthropology of Work Review 32: 103-14.

920 URL: https://doi.org/10.1111/j.1548-1417.2011.01062.x.

Ofstehage, A. 2012. The construction of an alternative quinoa economy: balancing solidarity,

922 household needs, and profit in San Agustín, Bolivia. Agriculture and Human Values 29:441-454.

URL: https://dx.doi.org/410.1007/s10460-10012-19371-10460.

924 Ostrom, E. 1990. Governing the commons: the evolution of institutions for collective action. New York, USA: Cambridge University Press.

926 Pouteau, R., S. Rambal, J.P. Ratte, F. Gogé, R. Joffre, and T. Winkel. Downscaling MODIS-derived maps using GIS and boosted regression trees: The case of frost occurrence over the arid Andean

928 highlands of Bolivia. Remote Sensing of Environment 115: 117-129. URL:

https://doi.org/10.1016/j.rse.2010.08.011

930 PUC (Pontificia Universidad Católica de Chile). 2017. Potencial competitivo de la quinua chilena. Santiago, Chile: Fundación para la Innovación Agraria (FIA). 
932 Rojas, W., ed. 2011. La quinua: cultivo milenario para contribuir a la seguridad alimentaria mundial. Santiago, Chile: FAO, Oficina Regional para America Latina y el Caribe.

934 Sáez-Tonacca, L., A. Aravena-Narbona, and C. Díaz Ramírez. 2018. Uso de harina de hojas de quínoa (Chenopodium quinoa) como ingrediente innovador, para la elaboración de alimentos

936 de uso humano. Idesia (Chile) 36: 233-242. URL: http://dx.doi.org/10.4067/S071834292018005000602.

938 Salcedo, S., and L. Guzmán. (Eds.). 2014. Agricultura familiar en América Latina y el Caribe: Recomendaciones de políticas. Santiago, Chile: FAO. URL:

940 http://www.fao.org/docrep/019/i3788s/i3788s.pdf.

Salliou, N. 2011. Rapport final pour la révision des montants de prix minimum et de prime pour

942 le quinoa labélisé Fairtrade Max Havelaar. France: Max Havelaar. URL: https://www.researchgate.net/profile/Nicolas_Salliou/publication/271964300.

944 Sinclair, K., A. Curtis, E. Mendham, and M. Mitchell. 2014. Can resilience thinking provide useful insights for those examining efforts to transform contemporary agriculture? Agriculture and

946 Human Values 31: 371-384. URL: http://doi.org/10.1007/s10460-014-9488-4

Slight, P., M. Adams, and K. Sherren. 2016. Policy support for rural economic development

948 based on Holling's ecological concept of panarchy. International Journal of Sustainable Development \& World Ecology 23: 1-14.

950 Soane, I. D., R. Scolozzi, A. Gretter, and K. Hubacek 2012. Exploring panarchy in alpine grasslands: an application of adaptive cycle concepts to the conservation of a cultural

952 landscape. Ecology and Society 17:18. doi: 10.5751/es-05085-170318

Soper, R. 2016. Local is not fair: indigenous peasant farmer preference for export markets.

954 Agriculture and Human Values 33: 537-548. URL: http://dx.doi.org/510.1007/s10460-1001519620-10460.

956 Soraide-Lozano, D. 2011. La Quinua Real en el altiplano sur de Bolivia: documento técnico para la denominación de origen. La Paz, Bolivia: Fundación FAUTAPO. 
958 Swiderska, K., A. Argumedo, Y. Song, A. Rastogi, N. Gurung, and C. Wekesa. 2018. Biocultural innovation: the key to global food security? London, UK: International Institute for Environment and Development (IIED). URL: http://pubs.iied.org/17465IIED/?p=17461.

Tittonell, P. 2014. Livelihood strategies, resilience and transformability in African agroecosystems. Agricultural Systems 126: 3-14.

Tschopp, M., S. Bieri, S., and S. Rist. 2018. Quinoa and production rules: How are cooperatives 964 contributing to governance of natural resources? International Journal of the Commons 12: 402427. URL: http://doi.org/10.18352/ijc.826.

966 Van der Ploeg, J.D. 2018. From de-to repeasantization: the modernization of agriculture revisited. Journal of Rural Studies 61: 236 43. URL:

968 https://doi.org/10.1016/j.jrurstud.2017.12.016.

Vassas-Toral, A. 2015. Movilidades, recursos de tierra y sistema de producción agrícola en el

970 altiplano sur de Bolivia. In Racionalidades campesinas en los Andes del sur: reflexiones en torno al cultivo de la quinua y otros vegetales andinos, eds., P. Cruz, R. Joffre, and T. Winkel. Jujuy,

972 Argentina: EdiUNJU, Universidad Nacional de Jujuy.

Vieira-Pak, M. 2015. El auge de la quinua: visiones de futuro en el altiplano sur de Bolivia. In

974 Racionalidades campesinas en los Andes del sur: reflexiones en torno al cultivo de la quinua y otros vegetales andinos, eds., P. Cruz, R. Joffre, and T. Winkel. Jujuy, Argentina: EdiUNJU, 976 Universidad Nacional de Jujuy.

Walker, B. H., and D. A. Salt. 2006. Resilience thinking: sustaining ecosystems and people in a 978 changing world. Washington DC, USA: Island Press.

Walsh-Dilley, M. 2013. Negotiating hybridity in highland Bolivia: indigenous moral economy and 980 the expanding market for quinoa. The Journal of Peasant Studies 40:659-682. URL: http://dx.doi.org/610.1080/03066150.03062013.03825770.

982 Walshe, R., and A. Argumedo. 2017. Ayni, ayllu, yanantin and chanincha: the cultural values enabling adaptation to climate change in communities of the Potato Park, in the Peruvian 
984 Andes. GAIA - Ecological Perspectives for Science and Society 25: 166-173. URL:

https://doi.org/110.14512/gaia.14525.14513.14517.

986 Winkel, T., R. Alvarez-Flores, D. Bertero, P. Cruz, C. Del Castillo, R. Joffre, S. Peredo Parada, and L. Sáez Tonacca. 2014. Calling for a reappraisal of the impact of the quinoa expansion on

988 agricultural sustainability in the Andean highlands. Idesia (Chile) 32: 95-100.

URL:http://dx.doi.org/10.4067/S0718-34292014000400012.

990 Winkel, T., R. A. Alvarez-Flores, P. Bommel, J. Bourliaud, M. Chevarria Lazo, G. Cortes, P. Cruz, C. Del Castillo, P. Gasselin, R. Joffre, F. Léger, J. P. Nina Laura, S. Rambal, G. Rivière, M. Tichit, J.F.

992 Tourrand, A. Vassas Toral, and M. Vieira-Pak. 2015. The southern altiplano of Bolivia. In State of the art report on quinoa around the world in 2013, eds. D. Bazile, D. Bertero and C. Nieto.

994 Rome, Italy: FAO. URL: http://www.fao.org/3/a-i4042e.pdf.

Winkel, T., H. D. Bertero, P. Bommel, M. Chevarría Lazo, G. Cortes, P. Gasselin, S. Geerts, R.

996 Joffre, F. Léger, B. Martinez Avisa, S. Rambal, G. Rivière, M. Tichit, J.F. Tourrand, A. Vassas Toral, J.J. Vacher, and M. Vieira-Pak. 2012. The sustainability of quinoa production in southern Bolivia:

998 from misrepresentations to questionable solutions. Journal of Agronomy and Crop Science 198: 314-319. URL: http://dx.doi.org/10.1111/j.1439-037X.2012.00506.x

1000 Winkel, T., P. Bommel, M. Chevarría-Lazo, G. Cortes, C. Del Castillo, P. Gasselin, F. Léger, J. P. Nina-Laura, S. Rambal, M. Tichit, J. F. Tourrand, J. J. Vacher, A. Vassas-Toral, M. Vieira-Pak, and 1002 R. Joffre. 2016. Panarchy of an indigenous agroecosystem in the globalized market: The quinoa production in the Bolivian altiplano. Global Environmental Change 39: 195-204. URL:

1004 https://doi.org/10.1016/j.gloenvcha.2016.05.007.

Zandstra, M. 2015. Powerfood: an analysis of relations between the state, local authorities and 1006 transnational networks in the production and sales of quinoa in Bolivia. MSc thesis. Amsterdam, The Netherlands: University of Amsterdam, Department of Global Environmental Politics and 1008 Governance. URL: http://www.scriptiesonline.uba.uva.nl/530111. 